\title{
Satellite observations of the effect of the "Godzilla El Niño" on the Tehuantepec upwelling system in the Mexican Pacific
}

Erik Coria-Monter', David Alberto Salas de León², María Adela Monreal-Gómez² and Elizabeth Durán-Campos ${ }^{3 *}$

\begin{abstract}
During 2015-2016, a strong El Niño, the "Godzilla El Niño," which is similar to El Niño events that occurred in 1982/1983 and 1997/1998, occurred in the Pacific Ocean. In this paper, we report on the influence of the "Godzilla El Niño" on the sea surface temperature (SST) and chlorophyll-a (Chla) concentrations in the Tehuantepec upwelling system using satellite observation data. A time-series of the SST and Chla levels in a circular site with a diameter of approximately $54 \mathrm{~km}$ centered at the fixed position $\left(15^{\circ} \mathrm{N}, 94.75^{\circ} \mathrm{W}\right)$ for the period from January 2003 to December 2016 was obtained using a Moderate Resolution Imaging Spectroradiometer. To estimate the vertical water velocity, a wind velocity time series was obtained from the Copernicus Marine Environment Monitoring Service to assess its variation over the period from January 2014 to December 2016. The results showed unusually high SSTs $\left(>28^{\circ} \mathrm{C}\right.$ ) and atypically low Chla concentrations $\left(<0.1 \mathrm{mg} \mathrm{m}^{-3}\right)$ in the domain of interest during the winter of $2015 / 2016$. In the region of study, the SST in January 2016 was $5.13^{\circ} \mathrm{C}$ higher than it had been in January of 2015, whereas the Chla concentration was $1.56 \mathrm{mg} \mathrm{m}^{-3}$ lower over this period. We found that the "Godzilla El Niño" impacted the Tehuantepec upwelling system in the following ways: (1) the wind and vertical water velocity during the winter of 2015/2016 were slightly higher than those observed during the winters of 2013/2014 and 2014/2015; (2) the coastal SST values were elevated during the winter of 2015/2016 compared to their levels during the previous two winters, revealing nutrientpoor water advection; and (3) the Chla concentrations during the 2015/2016 winter season were unusually low compared to their levels during the previous two winters. Our interpretation of these results is that in the Tehuantepec Gulf the wind was strong and induced vertical water velocities reaching up to $6 \mathrm{~m}$ day ${ }^{-1}$ during the "Godzilla El Niño" event (winter 2015/2016); however, the levels of Chla during this period were lower than they had been in previous years. In particular, the levels were lower than they had been during the previous winters. This suggests that, although the wind during the event favored strong upwelling, the water that was advected to the upper layer was nutrient poor.
\end{abstract}

Keywords: Chlorophyll-a, Godzilla El Niño, Sea surface temperature, Tehuantepec upwelling system

\section{Introduction}

The Gulf of Tehuantepec is located along the Mexican margin of the eastern tropical North Pacific (Fig. 1a). Because of its location within a region where the Intertropical Convergence Zone shifts latitudinally, seasonally, and interannually, the gulf exhibits several

\footnotetext{
*Correspondence: eduran@cmarl.unam.mx

${ }^{3}$ Unidad Académica Mazatlán, Instituto de Ciencias del Mar y Limnología, Universidad Nacional Autónoma de México, Explanada de la Azada y

Cerro del Crestón, 82040 Mazatlán, Sinaloa, Mexico

Full list of author information is available at the end of the article
}

climatic and oceanographic processes. One of them is an upwelling system that induces high primary productivity. This productivity in turn supports abundant and productive fisheries that provide primarily shrimp, tuna, and shark $[10,19]$.

In the Gulf of Tehuantepec, northerly winds occur throughout the year [28]. Although in the summer these winds $\left(\sim 10 \mathrm{~m} \mathrm{~s}^{-1}\right)$ are not as intense as they are in the winter $\left(\sim 20 \mathrm{~m} \mathrm{~s}^{-1}\right)$, they induce vertical water velocities ranging from 0.11 to $1.64 \mathrm{~m} \mathrm{day}^{-1}$ [2]. The comma-shaped Tehuantepec upwelling system 

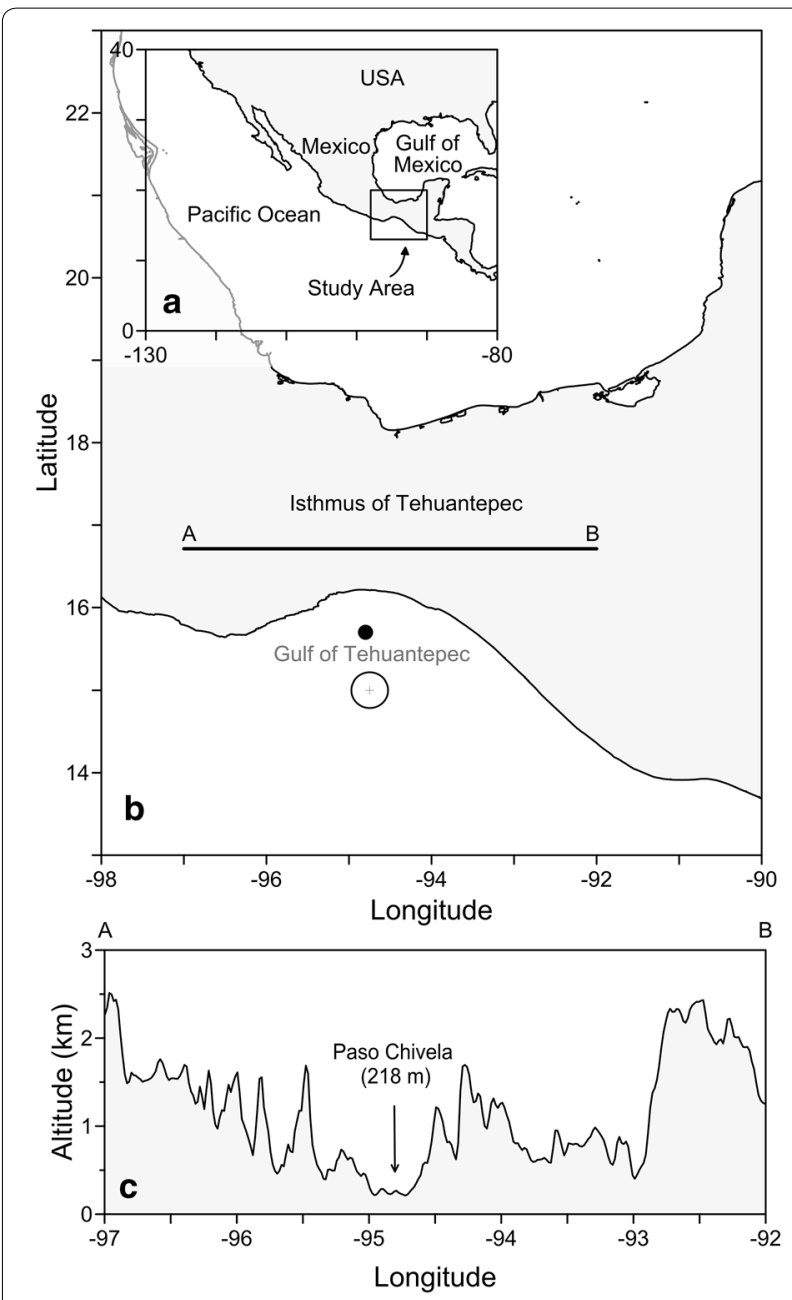

Fig. 1 a Study area; $\mathbf{b}$ the Gulf of Tehuantepec. The circle represents an area with $\mathrm{a} \approx 54 \mathrm{~km}$ in diameter. The black point was selected to analyze the wind conditions; and $\mathbf{c}$ section showing the altitude $(\mathrm{km})$ of Paso Chivela

is induced by strong winds $\left(>10 \mathrm{~m} \mathrm{~s}^{-1}\right)$ from the Gulf of Mexico (referred to locally as "tehuanos"). In the upwelling process, as the wind passes over the Isthmus of Tehuantepec (Paso Chivela; Fig. 1c), the wind perpendicular to the coast facilitates the movement of the surface water seaward. The surface water is replaced by cold, subsurface, nutrient-rich water that fertilizes the euphotic zone and supports the region's primary and secondary production from November to April [3, 10, 23]. In regions where upwelling is present throughout the year, nutrients tend to be unlimited and primary production levels are generally high. However, the occurrence, persistence, and intensity of these highly productive systems can be impacted on interannual time scales by changes in the weather conditions associated with the El Niño-Southern Oscillation (ENSO).
A reduction in the intensity of a classical wind-driven coastal upwelling can limit the nutrient supply and negatively impact primary production and fisheries [9], which can cause the loss of tens of billions in U.S. dollars [18].

The National Oceanic and Atmospheric Administration (NOAA) forecasted a strong ENSO event that was to occur during the winter of 2015-2016 [15]. It was named the "Godzilla El Niño" [26] and the event was predicted to be similar to those that occurred during $1982 / 1983$ and $1997 / 98$. The latter of these events was referred to as "the climate event of the twentieth century" [7].

Some authors have evaluated the effects of the previous ENSO events in the Gulf of Tehuantepec and adjacent regions. During 1987, an ENSO year, unusual warm coastal waters, followed by high coral mortality rates, were documented [12]. Based on satellite observations, Aguirre-Gómez et al. [1] observed a rise in Sea Surface Temperature (SST) of between 3 and $4{ }^{\circ} \mathrm{C}$ during the 1997/1998 ENSO event and the inhibition of upwelling. Romero-Centeno et al. [24] noted an influence of the ENSO events on the interannual variability in the winds over the Gulf of Tehuantepec. They observed an increase in the wind speed and an effect on the upwelling system in the Gulf of Tehuantepec.

To date, there has been no research on the effects of the "Godzilla El Niño" on the Gulf of Tehuantepec coastal upwelling system. Our goal was to assess the effect of this climate disruption on the variations in the sea surface temperature and the phytoplankton biomass. The latter was studied by measuring the chlorophyll-a (Chla) concentration in the Tehuantepec upwelling system using data derived from satellite observations obtained during the period from January 2003 to December 2016.

The study of extreme ENSO events is vitally important for understanding the influence of these phenomena on higher trophic levels and improving our ability to construct diagnostic and predictive models.

\section{Materials and methods}

To study the ENSO phenomena during the period from January 2003 to December 2016, we obtained data from two different indices: the Multivariate ENSO Index (MEI) from the NOAA Earth System Research Laboratory (www.esrl.noaa.gov/) and the NIÑO 3.4 from the NOAA Working Group on Surface Pressure (https://www.esrl. noaa.gov/psd/gcos_wgsp/Timeseries/Nino34/). The MEI is derived from several oceanographic and meteorological parameters, including sea-level pressure, zonal and meridional components of the sea surface wind, sea surface temperature, surface air temperature, and cloudiness 
fraction of the sky, over the tropical Pacific and reflects the nature of the coupled ocean-atmosphere system better than other indices [33]. Large positive MEI values indicate El Niño conditions, while large negative values indicate La Niña conditions. Measurements for the Niño 3.4 index have been collected and recorded for decades. These observational data are easily accessible via the Internet and have been widely used for managing food security policies [22, 29]. Satellite images of SST and Chla during the period (2014-2016) in which the Godzilla El Niño took place were obtained from the NASA Data Browser (https://oceancolor.gsfc.nasa.gov/cgi/browse.pl). The images, which had a spatial resolution of $1 \mathrm{~km} /$ pixel, were processed as follows: before mapping (Level 2), the values of the SST and Chla were extracted using SeaDAS version 7.4. To filter out low-quality data as the images were generated, LAND, CLDICE, HILT, and STRAYLIGHT flags/masks were applied. When a pixel from a MODIS L2 image was flagged, it was masked by LAND and CLDICE. HILT was flagged if any of the bands or detectors reaches physical saturation, whereas STRAYLIGHT showed the brightness of adjacent pixels on a pixel's reflectance value [21]. After this, maps for each month for both SST and Chla were generated using Matlab [17].

Using standard algorithms, time-series of SST and Chla on cloudless days were obtained using the Moderate Resolution Imaging Spectroradiometer (MODIS) during the period from January 2003 to December 2016. As already discussed, the selected time period is representative of the variability in the surface waters of the gulf, before, during and after the ENSO event. MODIS orbits around the Earth from north to south across the equator in the morning and from south to north over the equator in the afternoon. The satellite acquires an image with high radiometric sensitivity in 36 spectral bands with a period of 1-2 days.

To quantitatively assess the variation in SST and Chla concentration, a disc-shaped site centered at $15^{\circ} \mathrm{N}$ and $94.75^{\circ} \mathrm{W}$ with an average diameter of $\approx 54 \mathrm{~km}$ was chosen (black circle in Fig. 1). The site was selected to exclude the coastline to minimize background error due to the presence of suspended organic matter. Next, we estimated the regional variation in both the SST and Chla concentration over the chosen time period. SST is a basic parameter phytoplankton communities, but variations in SST also reflect changes in the mixing and advection of surface waters as well as changes in the air-sea fluxes that are associated with daily weather fluctuations. To obtain the desired variations in these parameters, we first obtained the SST and Chla typical values or yearly means, which were obtained by calculating the daily average with respect to time over the 14 year time series.
The SST and Chla anomalies were obtained by subtracting these mean values from the observed SST and Chla concentration values.

To assess the variations in the wind during the period from January 2014 to December 2016, a wind velocity time series at $16.16^{\circ} \mathrm{N}$ and $95.2^{\circ} \mathrm{W}$ (black point in Fig. 1b) was obtained from the Copernicus Marine Environment Monitoring Service (http://marine.copernicus.eu). These wind data were used to estimate the vertical water velocity at the base of the upwelling layer $w_{H}\left(=\frac{\tau_{s y}}{f \rho L}\right)$ [5], where $f$ is the Coriolis parameter, $\rho$ is the water density, $L$ is the extension of upwelling or distance from the $y$-axis, and $\tau_{s y}\left(\rho_{a} C_{d}|\vec{W}| W_{y}\right)$ is the seaward component of wind stress (perpendicular to the coast), which depends on air density $\left(\rho_{a}\right)$, drag coefficient $\left(C_{d}\right)$, wind speed $(|\vec{W}|)$, and seaward component of the wind velocity $\left(W_{y}\right)$.

\section{Results}

The intertropical convergence zone around the equator is marked by high convection and energy fluxes, resulting in persistent cloudy conditions and only several weeks of clear sky during the year. However, satellite observations reveal clear SST and Chla signals in the domain of interest.

Our time series are derived from satellite observations and include data from January 2003 to December 2016 . The figures below only show the period when the Godzilla El Niño took place (2014-2016); the complete time series show that the NIÑO 3.4 is maximum $(>2.0)$ during the period coincident with the Godzilla El Niño (Fig. 2a). The Multivariate ENSO Index (MEI) is positive (>1.0) during the years 2007, 2010, and 2015-2016, indicative of El Niño conditions, but is negative during 2008, 2011, and 2012, indicative of La Niña condition (Fig. 2b). The data also show that there is a wide seasonal variability in SST and Chla between the winter and summer months, i.e., high Chla concentrations during the winter months and low Chla concentrations during the summer (Fig. 2c). These results are consistent with the values obtained by the anomalies of both variables (Fig. 2d). From Fig. 2c, we see that the Chla concentration decreases dramatically during 2015 due to the abrupt increase in SST.

During the period when the Godzilla El Niño occurs, the MEI is positive and achieves its maximum (2.2) during the 2015/2016 winter. This indicates high SSTs (Fig. 2b), which agrees with results from studies of the two previous ENSO events, where values of 2.5 and 2.2 were reported for the 1982/1983 and 1997/1998 events, respectively [33]. The monthly variation in SST and the Chla concentration at the selected fixed position and 

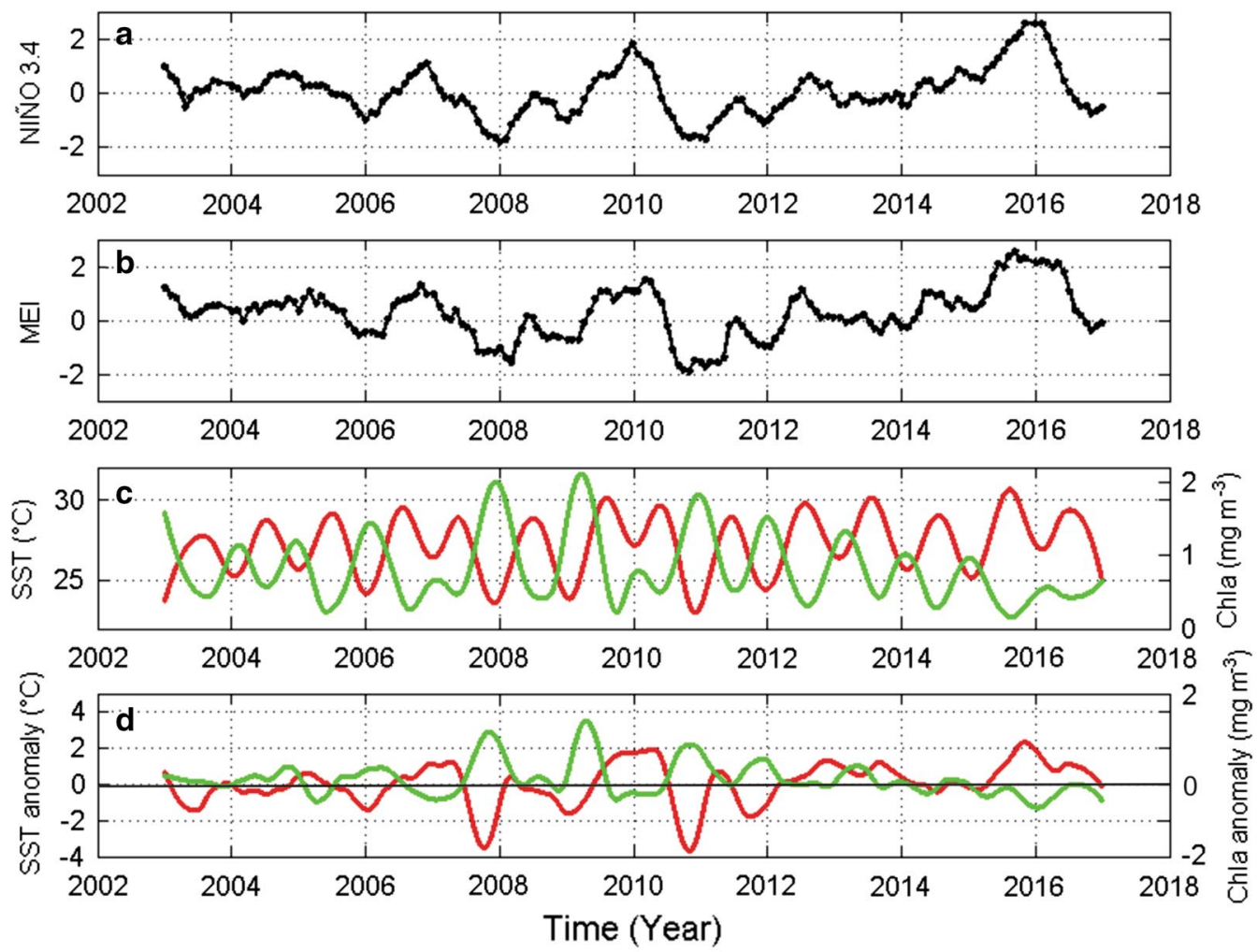

Fig. 2 Time series for the period from January 2003 to December 2016 of: a The NIÑO 3.4 index; b Multivariate ENSO Index (MEI); c SST ( ${ }^{\circ} \mathrm{C}$, red line) and Chla concentration ( $\mathrm{mg} \mathrm{m}^{-3}$, green line) at a fixed position $\left(15^{\circ} \mathrm{N}, 94.75^{\circ} \mathrm{W}\right.$ ) averaged for a circular area $\approx 54 \mathrm{~km}$ in diameter; and $\mathbf{d}$ data anomalies of SST (red line) and Chla (green line)

its average over the selected domain (Fig. 2c) show a decrease in the Chla concentration of $1.56 \mathrm{mg} \mathrm{m}^{-3}$ due to the "Godzilla El Niño" during the winter of 2015/2016 that is associated with a $5.13{ }^{\circ} \mathrm{C}$ increase in the surface water temperature. The time series show the differences in SST and Chla concentration between January 2015 and January 2016; they also show that during December of 2016, the SST $\left(\sim 22^{\circ} \mathrm{C}\right)$ returns to "neutral," or nonENSO, conditions in the Tehuantepec gulf. Figure 2c shows that when the SST increases, the Chla concentration decreases. Correlation analysis performed to support these observations reveals an inverse $(R=-0.67)$ and statistically significant relationship $(p=0.00001)$ between the parameters. Figure $2 \mathrm{~d}$ shows that the positive anomalies in the SST are associated with the months in which the "Godzilla El Niño" occurred.

During 2014, before the "Godzilla El Niño" event (Fig. 3), the satellite images show that an area of upwelling extends off the coast. The SST ranges from 23.1 to $29.8{ }^{\circ} \mathrm{C}$, reaching its maximum in May (Fig. 3e) and minimum during November when a strong cold tongue is observed (Fig. 3k). The Chla concentration ranges from 0.06 to $2.09 \mathrm{mg} \mathrm{m}^{-3}$, achieving a maximum during the winter when high concentration patches are observed as a result of an upwelling during the season.

During 2015 (Fig. 4), the Chla images clearly show the presence of a comma-shaped area representing the January, February, and March upwelling system (Fig. $4 \mathrm{a}-\mathrm{c}$ ). During this year, the SST rises from 22.4 to $30.6{ }^{\circ} \mathrm{C}$, achieving its maximum value during the summer (Fig. $4 \mathrm{f}-\mathrm{h}$ ). However, high values up to $28.8^{\circ} \mathrm{C}$ are observed for November and December (Fig. $4 \mathrm{k}-\mathrm{l}$ ). The Chla concentration varies from 0.14 to $2.80 \mathrm{mg} \mathrm{m}^{-3}$ and reaches its highest values during January, February, and March. A minimum is reached during the summer. These values show a dependence on SST, i.e., as SST increases, the Chla concentration decreases. The presence of clouds creates some gaps in the data, particularly during July, August, and September; however, it is possible to obtain and visualize the distribution of both variables.

In January, February, and March of 2016, a region of cold water with a high Chla concentration is observed; however, it does not have the same extension or intensity as the upwelling event in 2014 does, nor is it as cold or Chla-enriched (Fig. 5a-c). During October, November, and December of 2016, a well-shaped upwelling system 

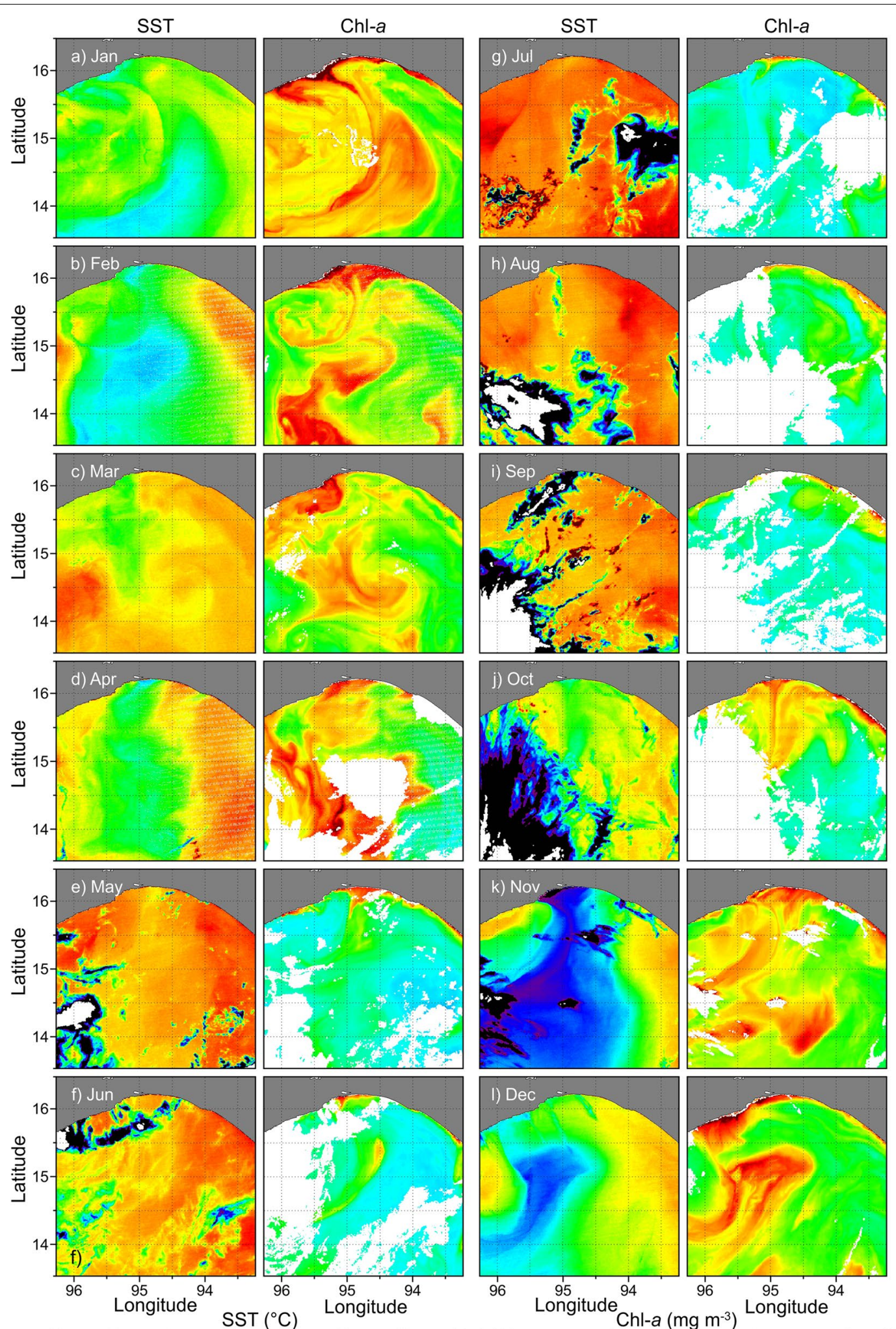

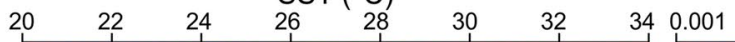

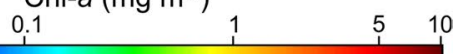

Fig. 3 Monthly images of SST $\left({ }^{\circ} \mathrm{C}\right)$ and Chla concentration $\left(\mathrm{mg} \mathrm{m}^{-3}\right)$ during 2014 

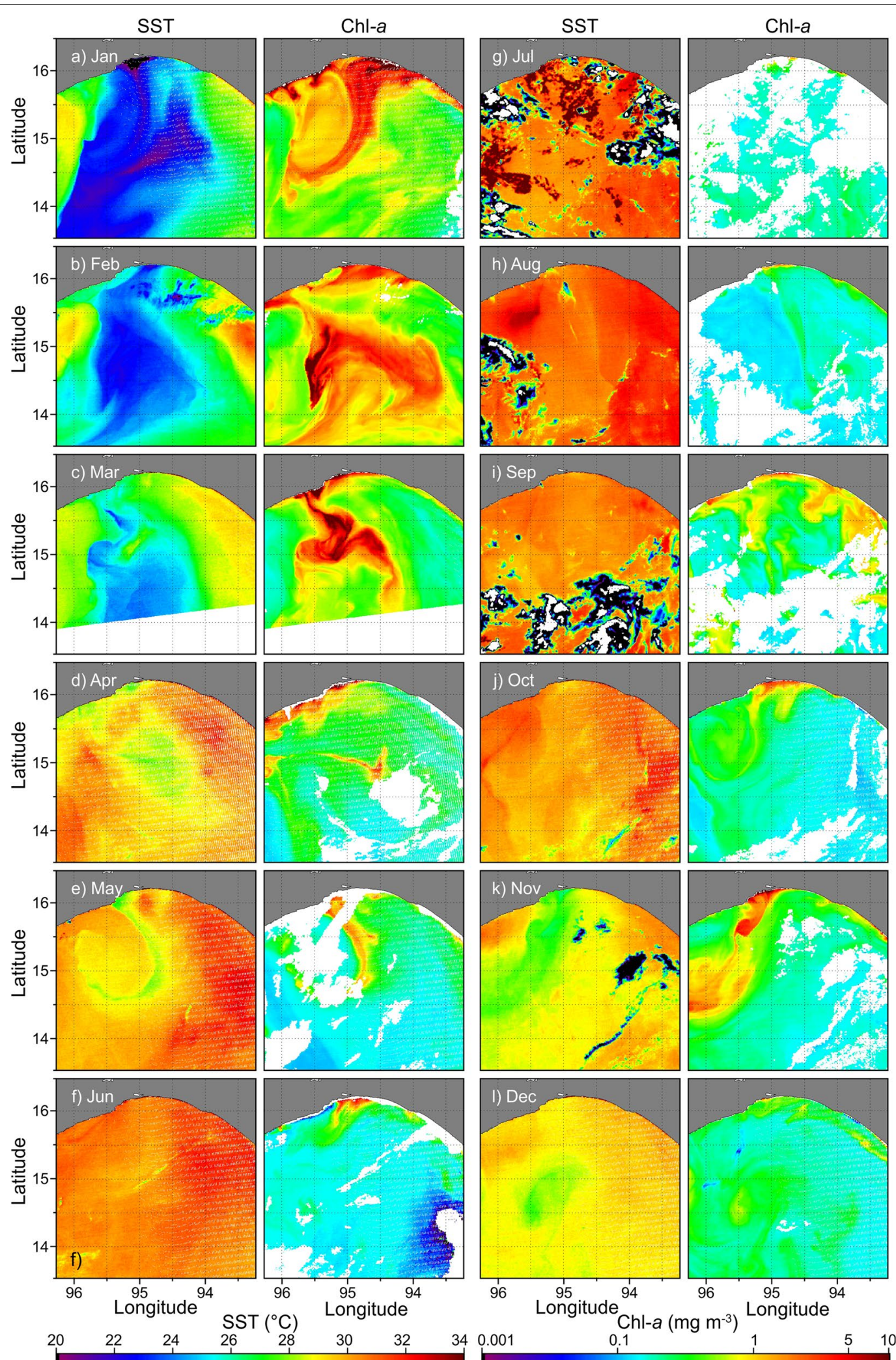

Fig. 4 Monthly images of SST $\left({ }^{\circ} \mathrm{C}\right)$ and Chla concentration $\left(\mathrm{mg} \mathrm{m}^{-3}\right)$ during 2015 
develops (Fig. 5j-1); this is in contrast with 2015, during which no signal is observed. The SST during OctoberDecember 2016 is higher than it is in 2015, achieving a maximum of $30.9^{\circ} \mathrm{C}$ during June and a minimum of only $20.6{ }^{\circ} \mathrm{C}$ in November. In January, the SST is high, reaching $>27.7{ }^{\circ} \mathrm{C}$. It increases $5.13{ }^{\circ} \mathrm{C}$ over its value in 2015 , as is shown in Fig. 2b. The Chla concentration during this year also shows changes with respect to 2015 and rises from 0.18 to $1.33 \mathrm{mg} \mathrm{m}^{-3}$, with a minimum during June (Fig. 5f). During January of 2015, the concentration of Chla is $2.00 \mathrm{mg} \mathrm{m}^{-3}$. During January 2016, it is $0.44 \mathrm{mg} \mathrm{m}^{-3}$, representing a decrease of $1.56 \mathrm{mg} \mathrm{m}^{-3}$. During 2016, the Chla concentration shows a similar trend as in 2015: as the SST increases, the Chla concentration decreases. As in the previous years, clouds generate some gaps in the data; however, it is possible to clearly visualize the patterns of distribution of both variables.

The wind time series show intensities of about $20 \mathrm{~m} \mathrm{~s}^{-1}$ during winter; an important northerly component is present throughout the period 2014/2016. However, during "Godzilla El Niño", a northeasterly wind (Fig. 6a), with values slightly higher than those observed during the 2013/2014 and 2014/2015 winters, (Fig. 6b) is present. The vertical water velocity reaches its maximum during the winter of $2015 / 2016$, when the Godzilla event is observed, i.e., when it reaches $6 \mathrm{~m} \mathrm{day}^{-1}$ (Fig. 6c).

\section{Discussion}

The impact of ENSO in the Mexican Pacific Ocean and adjacent areas has been well documented. The focus has been on strong events that modulated the sea surface temperature and nutrient and Chla concentrations. In the southern Gulf of California, near its connection with the Pacific Ocean, El Niño in 1982/1983 caused an increase in SST $\left(\approx 3-3.5^{\circ} \mathrm{C}\right)$ and a considerable ecosystem modification that negatively affected the distribution of silicoflagellates and other phytoplankton populations living in the Pacific Ocean [20]. During the 1997-1998 event, a clear impact on the SST and salinity fields was documented off Baja California [8] that induced low levels of Chla (average concentration of $0.13 \mathrm{mg} \mathrm{m}^{-3}$ ) [16]. Recently, based on satellite observations during the period from 2002 to 2015, the impact of ENSO events on the southern Gulf of California, which induced high SST values $\left(>24{ }^{\circ} \mathrm{C}\right)$, low Chla concentrations $\left(<2.00 \mathrm{mg} \mathrm{m}^{-3}\right)$, and moderate winds [11], was detected. This was particularly notable during the years 2002 and 2009, when moderate ENSOs took place. However, during 2015, an increase in SST was shown (up to $\approx 26.5^{\circ} \mathrm{C}$ ) and low levels of Chla were observed $\left(<2.00 \mathrm{mg} \mathrm{m}^{-3}\right)$ [11].

It has been established that ENSO affects the Mexican Pacific Ocean in two principal ways: (1) it is associated with a reduction in the upwelling productivity and raises the ocean temperature by $\approx 5{ }^{\circ} \mathrm{C}$ [24]; and (2) the southward motion of warm equatorial waters combined with high solar radiation at the surface induces an increase in sea surface temperature, which in turn reduces the primary biological productivity. Zamudio et al. [34] pointed out that the ENSO event that occurs along the southwest coast of Mexico has three distinct stages: (1) the generation of a coastal jet characterized by strong vertical shear flow; (2) an increase in the horizontal component of the shear flow along with an increase in the amplitude of its oscillations; and (3) the development of an instability in the jet, in which it breaks into anticyclonic eddies that separate from the coast and drift southwestward.

The results of this study reveal a clear impact of the "Godzilla El Niño" on the Chla concentrations in the Tehuantepec upwelling system. Based on satellite observations, Aguirre-Gómez et al. [1] identified a slight increase in the sea surface temperature from 3 to $4{ }^{\circ} \mathrm{C}$ during the 1997/1998 ENSO in the Gulf of Tehuantepec; the authors emphasize an inhibition of the upwelling events in the gulf compared with previous and subsequent years; their wind and vertical water velocity values were shown to favor the development of the upwelling. The increase of SST observed by the authors is in agreement with the results of this study, where an increase in SST of $5.13^{\circ} \mathrm{C}$ resulted in a dramatic decrease in the Chla concentration in January 2016 compared with its value in January 2015, resulting in a difference of $1.56 \mathrm{mg} \mathrm{m}^{-3}$.

Similar observations have been documented for other regions, such as for the Peruvian upwelling system (also known as the Northern Humboldt Current System), where a pronounced bottom-up control mechanism was observed during the 1982/1983 ENSO years that resulted in a decrease in primary production associated with Chla-poor waters $\left(<0.3 \mathrm{mg} \mathrm{m}^{-3}\right)[9,30]$. Values varying from 0.5 to $1 \mathrm{mg} \mathrm{m}^{-3}$ were reported during the $1997 / 1998$ ENSO in the same region [6]. Most recently, using a regional coupled physical-biogeochemical model, Espinoza-Morriberón et al. [9], studied the dynamical processes involved in the productivity changes during El Niño events in the Peruvian system, where the nutrient content decreased dramatically (especially nitrate and iron). This in turn affected the phytoplankton growth (particularly diatoms) and triggered habitat changes, such as a high mortality for several fish populations.

In studies of the effects of ENSO events on the California Current System, significant chemical and biological perturbations have been documented. During the $1997 / 1998$ events, the nutrient levels were limited substantially, which reduced the area available for biological production, increased the survival rate at higher tropical levels, and increased the flux of carbon dioxide from the ocean to the atmosphere [4]. Based on satellite-derived 

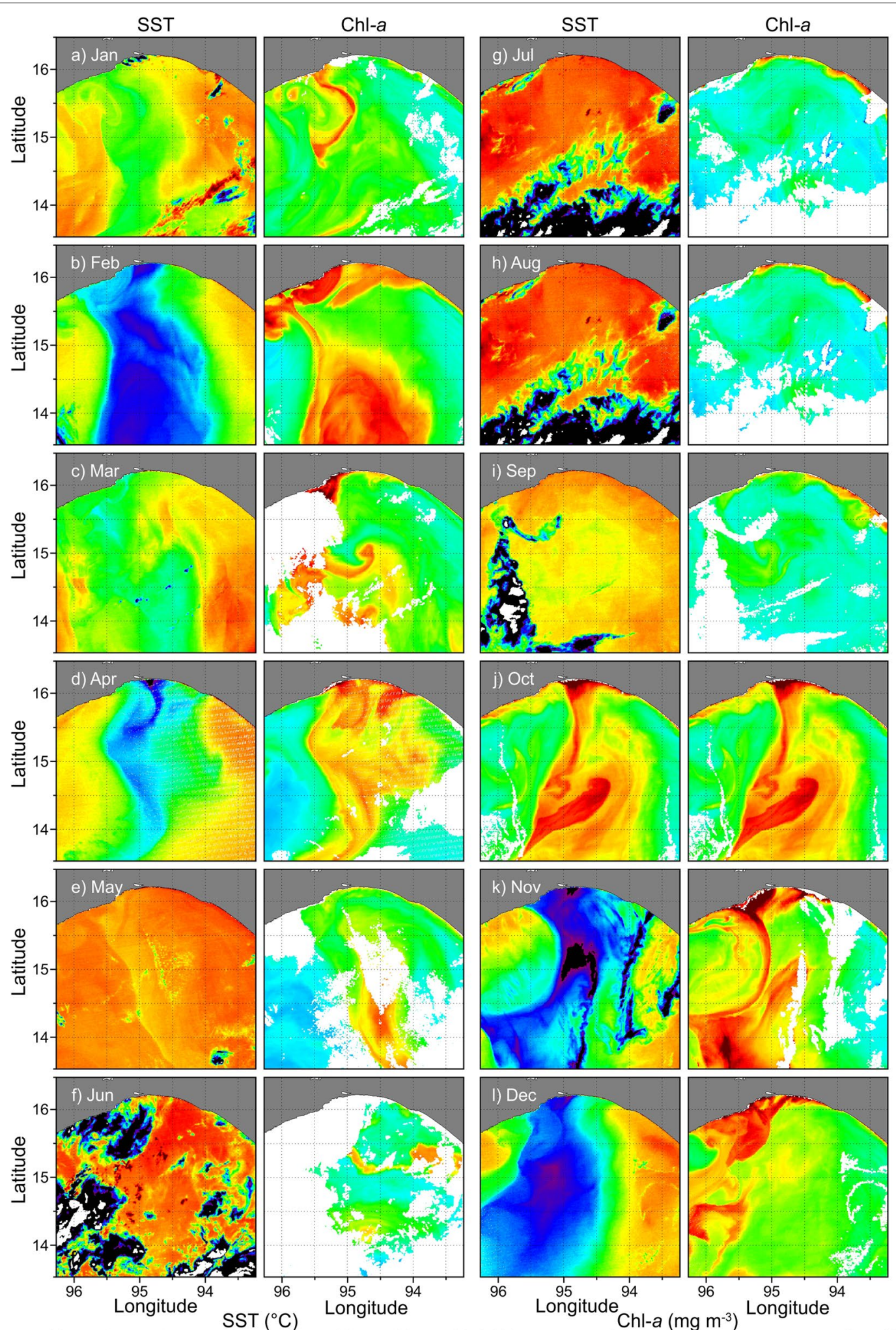

$\begin{array}{llllllll}20 & 22 & 24 & 26 & 28 & 30 & 32 & 34\end{array}$

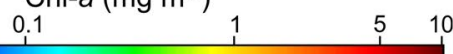

Fig. 5 Monthly images of SST $\left({ }^{\circ} \mathrm{C}\right)$ and Chla concentration $\left(\mathrm{mg} \mathrm{m}^{-3}\right)$ during 2016 
$\mathrm{N}$ a

Wind Speed $20\left(\mathrm{~m} \mathrm{~s}^{-1}\right)$
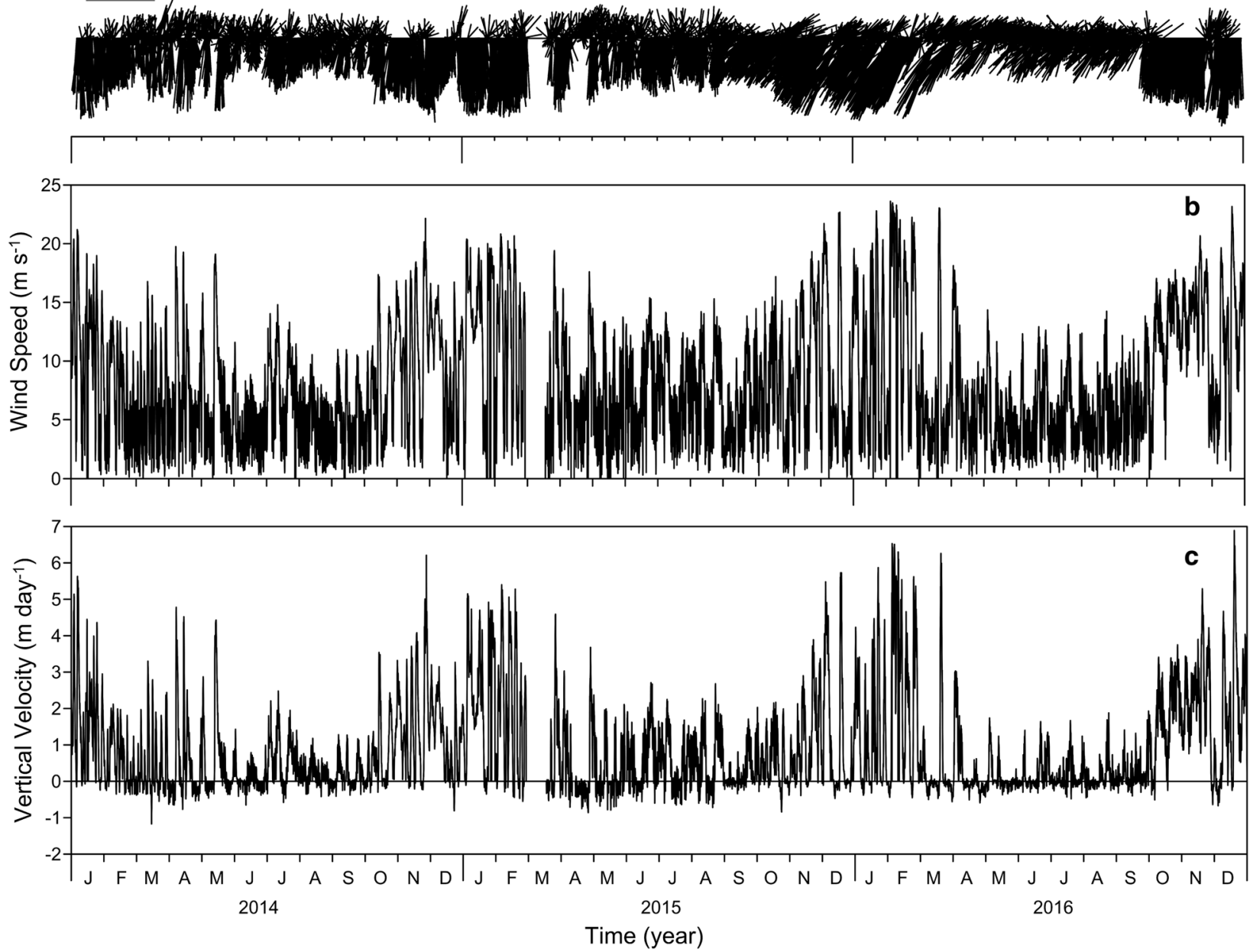

Fig. 6 a Wind velocity $\left(\mathrm{m} \mathrm{s}^{-1}\right)$, b wind speed time series (every $3 \mathrm{~h}$ ) obtained from Copernicus Marine Environment Monitoring Service, and $\mathbf{c}$ vertical water velocity $\left(\mathrm{m}\right.$ day $\left.{ }^{-1}\right)$

ocean color, similar observations were made by Kahru and Mitchell [13], who documented a significant decrease in surface Chla $\left(<0.10 \mathrm{mg} \mathrm{m}^{-3}\right)$ off the U.S. west coast during the 1997/1998 ENSO. The impact of this event on the northern Chile upwelling system was also addressed by Thomas et al. [31]. Based on satellite observations, they documented strong variations in both SST and Chla, which had a negative impact on the whole area.

To date, several consequences of the "Godzilla El Niño 2015/2016" event have been documented with respect to various domains of interest in the Pacific Ocean. For example, the warmest water and strongest convection was reported to be hundreds of kilometers farther west along the Equator during this event than during previous events [14]. Two strong anomalies were documented in the eastern North Pacific: anomalous winds from the south, which weakened nutrient transport and resulted in substantial decreases in phytoplankton biomass, and a $3.5^{\circ} \mathrm{C}$ increase in water temperature by January [32]. An abnormal increase in temperature led to decreased densities and nutrient concentrations in the upper $350 \mathrm{~m}$ at the Equator [27].

Santoso et al. [25] examined several variables that are relevant to ENSO genesis that characterized the $2015 / 2016$ event. They found that the $2015 / 2016$ event was marked by a record-breaking warm anomaly in the central Pacific, revealing similarities between this event and the 1982/1983 and 1997/1998 events.

The monthly and inter-annual variability in SST and Chla concentration has been widely attributed to ENSO events. For instance, in the Gulf of California, an important association was observed between the values of these variables and the months with negative ENSO anomalies (La Niña), i.e., high Chla concentration values and low 
SST values. Months with positive ENSO anomalies (El Niño) were correlated with high SST values and low Chla concentrations [11] results which agree with our observations. Significant inter-annual differences in climate index values were observed, i.e., the years with high SST values, such as 2009 , were correlated with large positive ENSO anomalies and were identified as strong El Niño years. Years with negative ENSO anomalies (2007-2008 and 2010-2011) had lower SST values and had moderate La Niña events [11].

Based on the observations presented in this study, there are three consequences of the effects of the "Godzilla El Niño 2015/2016" on the Tehuantepec upwelling: (1) wind velocities and vertical water velocity were higher during this event than those observed during the 2013/2014 and 2014/2015 winters; (2) SST values were higher $\left(>28^{\circ} \mathrm{C}\right.$ ) off the coast during winter $2015 / 2016$ than they were during the previous winters, with a rise of $5.13{ }^{\circ} \mathrm{C}$ between January 2015 and January 2016; and (3) the Chla concentration was lower $\left(<1 \mathrm{mg} \mathrm{m}^{-3}\right)$, which suggests the advection of nutrient-poor waters.

Although there were no measurements of the primary productivity in the Gulf of Tehuantepec during this event, it is assumed that there was a marked effect on the phytoplankton community and thus on the biological productivity. Because the impacts of ENSO tend to be more dramatic during extreme events, the changes associated with the structure of the water column and Chla surface concentration can lead to significant fatalities, economic loss, and large-scale environmental degradation $[9,25]$. Our interpretation is that the wind and vertical water velocity slightly increased in the Tehuantepec gulf during the "Godzilla El Niño" event (winter 2015/2016); however, the levels of Chla were lower compared to previous years, particularly in the winter season. This indicates that although the wind favored strong upwelling, the upwelled water was oligotrophic.

The results of this study show that, from a synoptic point of view, the use of remote sensing for monitoring large-scale processes leads to a better understanding of systems in which the high biological productivity influences the economy of the region. However, many more detailed studies are required, including in situ and satellite observations as well as numerical modeling, to understand the impact of these ENSO events on higher trophic levels, address globally relevant questions, and improve the predictability, preparedness, and response on seasonal time-scales to this abnormal climate disruption. Finally, the results presented here highlight the value of efforts to improve knowledge of the effects of the largest ENSO event on record on systems with high biological productivity.

\section{Authors' contributions}

ECM conceptualized the study, designed the methodology, and wrote the initial manuscript. DASL conceptualized the study and analyzed the data set. MAMG conceptualized the study and wrote the manuscript. EDC conceptualized the study, designed the methodology, and analyzed the data set. All authors read and approved the final manuscript.

\section{Author details \\ ${ }^{1}$ Cátedras CONACYT, Instituto de Ciencias del Mar y Limnología, Universi- dad Nacional Autónoma de México, Av. Universidad 3000, Col. Copilco, Del. Coyoacán, 04510 Mexico City, Mexico. ${ }^{2}$ Unidad Académica de Ecología y Biodiversidad Acuática, Instituto de Ciencias del Mar y Limnología, Universi- dad Nacional Autónoma de México, Av. Universidad 3000, Col. Copilco, Del. Coyoacán 04510 Mexico City, Mexico. ${ }^{3}$ Unidad Académica Mazatlán, Instituto de Ciencias del Mar y Limnología, Universidad Nacional Autónoma de México, Explanada de la Azada y Cerro del Crestón, 82040 Mazatlán, Sinaloa, Mexico.}

\section{Acknowledgements}

We appreciate Jorge Castro for assistance with the figures and Kevin Contreras for time-series wind speed data. Two anonymous reviewers enabled us to significantly improve the manuscript.

\section{Competing interests}

The authors declare that they have no competing interests.

\section{Availability of data and materials}

The datasets generated during this study are available upon request to corresponding author.

\section{Consent for publication}

Not applicable.

\section{Ethics approval and consent to participate}

Not applicable.

\section{Funding}

Consejo Nacional de Ciencia y Tecnología (CONACYT) provided funding to ECM for this study. This study was also supported by institutional grants from the Instituto de Ciencias del Mar y Limnología of the Universidad Nacional Autónoma de México (Grants \# 144, 145 and 342).

\section{Publisher's Note}

Springer Nature remains neutral with regard to jurisdictional claims in published maps and institutional affiliations.

Received: 11 December 2018 Accepted: 15 April 2019

Published online: 22 April 2019

\section{References}

1. Aguirre-Gómez R, Salmerón-García O, Álvarez-Béjar R. Satellite observations of the effect of ENSO on the Tehuantepec and Papagayo upwellings. Interciencia. 2012;37(11):828-32.

2. Araico-Gonzalez Cl. Circulación y estructuras de mesoescala en el Golfo de Tehuantepec a partir de observaciones hidrográficas y altimetría satelital. Tesis de maestría Posgrado en Ciencias del Mar y Limnología UNAM 2018 (in Spanish)

3. Barton ED, Lavín MF, Trasviña A. Coastal circulation and hydrography in the Gulf of Tehuantepec, Mexico, during winter. Cont Shelf Res. 2009;29(2):485-500.

4. Bograd S, Lynn R. Physical-biological coupling in the California Current during the 1997-99 El Niño-La Niña cycle. Geophys Res Lett. 2001;28(2):275-8.

5. Bowden KF. Physical oceanography of coastal waters. New York: Wiley; 1983

6. Carr ME, Strub PT, Thomas AC, Blanco JL. Evolution of 1996-1999 La Niña and El Niño conditions off the western coast of South America: a remote sensing perspective. J Geophys Res. 2002;107(C12):3236. 
7. Changon SA. El Niño 1997-1998: the climate event of the century. New York: Oxford University Press; 2000

8. Durazo R, Baumgartner TR. Evolution of oceanographic conditions off Baja California 1997-1998. Prog Oceanogr. 2002;54(1-4):7-31.

9. Espinoza-Morriberón DV, et al. Impacts of El Niño events on the Peruvian upwelling system productivity. J Geophys Res. 2017;122:5423-44.

10. Fernández-Alamo MA, Sanvicente-Añorve L, Alameda de la Mora G. Copepod assemblages in the Gulf of Tehuantepec, Mexico. Crustaceana. 2000:73(9):1139-53.

11. García-Morales R, et al. Environmental variability and oceanographic dynamics of the central and southern coastal zone of Sonora in the Gulf of California. Remote Sens. 2017;9(9):925.

12. Glynn PW, Leyte-Morales G. Coral reefs on Huatulco, West Mexico: a reef development in upwelling Gulf of Tehuantepec. Rev Biol Trop. 1997;45(3):1033-47.

13. Kahru M, Mitchell G. Influence of the 1997-98 El Niño on the surface chlorophyll in the California Current. Geophys Res Lett. 2000;27(18):2937-40.

14. Kintisch E. How a 'Godzilla' El Niño shook up weather forecasts. Science. 2016;352(6293):1501-2

15. Klein K. NOAA predicts strong El Niño. EOS Trans Am Geophys Union. 2015;96.

16. Lavaniegos BE, Jiménez-Pérez LC, Gaxiola-Castro G. Plankton response to El Niño 1997-1998 and La Niña 1999 in the southern region of the California Current. Prog Oceanogr. 2002;54(1-4):33-58.

17. Mathworks, Inc. MATLAB. Global optimization toolbox: user's guide (r2011b). www.mathworks.com/help/pdf_doc/gads/gads_tb.pdf (2011)

18. McPhaden MJ, Zebiak SE, Glantz MH. ENSO as an integrating concept in earth science. Science. 2006;314(5806):1740-5.

19. Molina-Cruz A, Martínez-López M. Oceanography of the Gulf of Tehuantepec, Mexico, indicated by Radiolaria remains. Palaeogeogr Palaeoclimatol Palaeoecol. 1994;1 10:179-95.

20. Pérez-Cruz L, Molina-Cruz A. El Niño 1983: effect on the distribution of silicoflagellates in the Gulf of California. Cienc Mar. 1988;14(3):9-38.

21. Pieri M, Massi L, Lazzara L, Nuccio C, Lapucci C, Maselli F. Assessment of three algorithms for the operational estimation of [CHLA] from MODIS data in the Western Mediterranean Sea. Eur J Remote Sens. 2015:48:383-401.
22. Rayner NA, Parker DE, Horton EB, Folland CK, Alexander LV, Rowell DP, Kent EC, Kaplan A. Global analyses of sea surface temperature, sea ice, and night marine air temperature since the late nineteenth century. J Geophys Res. 2003;108(D14):4407.

23. Robles-Jarero EG, Lara-Lara R. Phytoplankton biomass and primary productivity by size classes in the Gulf of Tehuantepec, Mexico. J Plank Res. 1993:15(12):1341-58.

24. Romero-Centeno R, Zavala-Hidalgo J, Gallegos A, O'Brien JJ. Isthmus of Tehuantepec wind climatology and ENSO signal. J Climatol. 2003;16:2628-39.

25. Santoso A, Mcphaden MJ, Cai W. The defining characteristics of ENSO extremes and strong 2015/2016 El Niño. Rev Geophys. 2017;55:1079-129.

26. Schiermeier Q. Hunting the Godzilla El Niño. Nature. 2015;526:490-1.

27. Stramma L, et al. Observed El Niño conditions in the eastern tropical Pacific in October 2015. Ocean Sci. 2016;12:861-73.

28. Stumpf HG, Legeckis RV. Satellite observations of mesoscale eddy dynamics in the Eastern Tropical Pacific Ocean. J Phys Oceanogr. 1977:7:648-58

29. Surmaini E, Wahyu Hadi T, Subagyono K, Tyasbudi Puspito N. Early detection of drought impact on rice paddies. Theor Appl Climatol. 2015;121:669-84

30. Taylor $\mathrm{MH}$, et al. Trophic modeling of the Northern Humboldt Current Ecosystem, Part II: elucidating ecosystem dynamics from 1995 to 2004 with focus on the impact of ENSO. Progr Oceanogr. 2008;79(2-4):366-78.

31. Thomas AC, Blanco JL, Carr ME, Strub PT, Osses J. Satellite-measured chlorophyll and temperature variability off northern Chile during the 1996-1998 La Niña and El Niño. J Geophys Res. 2001;106(C1):899-915.

32. Whitney FA. Anomalous winter winds decrease 2014 transition zone productivity in the NE Pacific. Geophys Res Lett. 2015;42:428-31.

33. Wolter K, Timlin MS. El Niño/Southern Oscillation behavior since 1871 as diagnosed in an extended multivariate ENSO index (MEl.ext). Int J Climatol. 2011;31:1074-87.

34. Zamudio L, Leonardi AP, Meyers SD, O'Brien JJ. ENSO and eddies on the southwest coast of Mexico. Geophys Res Lett. 2001;28(1):13-6.
Ready to submit your research? Choose BMC and benefit from:

- fast, convenient online submission

- thorough peer review by experienced researchers in your field

- rapid publication on acceptance

- support for research data, including large and complex data types

- gold Open Access which fosters wider collaboration and increased citations

- maximum visibility for your research: over 100M website views per year

At BMC, research is always in progress.

Learn more biomedcentral.com/submissions 